\title{
Nutritional status and dietary pattern in elderly population of Allahpur block in district Bijnor
}

\author{
Umita Kumari ${ }^{1}$, Kirti M. Tripathi ${ }^{*^{2}}$, Manoj Kumar ${ }^{3}$ and Satish Kumar ${ }^{4}$ \\ ${ }^{1}$ Ph.D Scholar C.C.S. University, Meerut \\ ${ }^{234}$ Krishi Vigyan Kendra, Bulandshahr (SVPUAT Meerut) \\ *Email: kirtitripathi.dixit@gmail.com
}

\begin{abstract}
The objective of this study was to assess the nutritional status of rural elderly population in Allahpur in district Bijnor and find out the dietary habits, clinical signs and symptoms and existing ailments of the selected respondents of rural areas of Allahpur Block. Six villages were selected. A sample of 100 respondents out of which 50 were males and 50 females, aged 60 years and above were selected. Respondents were personally interviewed with the help of pre-tested interview schedule by visiting the six villages. The schedule collected the data regarding the anthropometric measurements, food habits, dietary pattern and clinical sign and symptoms of the respondents. Height in $\mathrm{cm}$ and weight in $\mathrm{kg}$ were measured with the help of weighing machine and measuring tape.
\end{abstract}

Keywords: Nutrition, dietary pattern, Bijnor, food habits.

Paper Cited: Kumari, U., Tripathi, K.M., Kumar, M. and Kumar, S. (2017). Nutritional status and dietary pattern in elderly population of Allahpur block in district Bijnor. South Asian Journal of Food Technology and Environment, 3(2): 562-567.

\section{Introduction}

The ageing is a physiological process. Old age is defined as the age of retirement. It is known that the elderly are at risk for nutritional disorders and malnutrition, including under nutrition, nutrient deficiencies and imbalances. A number of age-related physical, clinical, economic and social factors can influence nutritional status; furthermore, changes in the body composition of elderly people and sedentary lifestyles reduce energy requirements and daily energy intakes. Nutrition is an essential determining factor of elderly over the age of 60 years.

Nutritional status is the condition of the body which majorly influenced by the diet; the levels of nutrients in the body and the ability of those levels to maintain normal metabolic integrity. Dietary patterns are defined as the quantities, proportions, variety or combinations of different foods, drinks and nutrients in diets, and the frequency with which they are habitually consumed. After 60 years there are many metabolic and physiological changes which lay impact on the nutritional needs of an individual. Aging is associated with decreased physical activity and metabolism thereby, the changes in the nutritional requirements of older adults. Balanced nutrient is very important for overall wellbeing. It becomes very important in the perspective of elderly due to physiological changes in the body. Immunity weakens with proceeding age which is influenced by lack of nutrients and differed dietary habits. Elderly are more prone to infections. Good nutrition is important at every stage of life for maintaining good health and personal productivity, and it is especially important to the elderly because of the physiological changes that occur in the body. Even in the best of circumstances, aging weakens the immune system. Insufficient calories, lack of protein, and micronutrient deficiencies in the elderly further weaken their immunity and expose them to infections that may reduce absorption of essential nutrients, thereby compounding the cycle of under nutrition and infection. Age-associated changes like dentition, taste and smell also influence food intake.

Smoking, alcohol consumption, and excessive use of medication are main causes of malnutrition in males. Nutrition is found to be a key factor for successful aging (Arulmani 
and John, 2004). Protein energy malnutrition is associated with an increased predisposition to illness, morbidity and mortality; this may change the quality of life (Omran and Hotley, 2000). Encouraging better nutrition and physical exercise is a cost-effective way of decreasing progression of age-related diseases (Fiatarone et al., 1994). Dentition, taste, smell, loss of memory and Parkinson disorders also influence food intake. A lower food intake among those who live alone may be affected by both functional capacities (including fatigue and mobility) and loneliness. A study revealed that elderly people living with their partners living in a better way than those without partner (Barette et al., 2006). As people age, adequate nutrition propels the maintenance of health, physical performance and psychological wellbeing (Bates et al., 2002; Nijs et al., 2006). Poor nutritional status refers to an inadequate or even excessive intake or utilisation of the nutrients to meet the body's requirements (Joshi, 2010). Malnutrition is a common problem among older people living in geriatric nursing homes (Saeidlou et al., 2011).

\section{Materials and Methods}

Area of study: Allahpur Block in district Bijnor was purposively selected due to the presence of more number of elderly people. Six villages namely Sherpur Kliya, Bakashanpur, Hariyana, Buapur Nathu, Ajitpur Dasi and Jaitra were selected due to easy approachability and elderly population.

Selection of respondents: The study was conducted among 100 respondents aged 60 years and above. Among them 50 were males and 50 females.

Study Design: Cross-sectional study

Data Collection Tool and Instruments: Pretested interview schedule, Weight Machine, Height Scale were used to collect the data and anthropometric measurement. A pre-tested interview schedule was used for collecting the data. The respondents were personally interviewed and information regarding general profile, diet, anthropometric measurements was gathered.

\section{Results and Discussion}

Table 1 shows the socio-demographic data of the respondents. Out of 100 respondents 50 percent were male and 50 percent were female. Majority of male respondents $70 \%$ and female respondents $74 \%$ were $60-70$ years old. $22 \%$ males and $20 \%$ females were 71-80 years old. Minimum number of male $8 \%$ and females $6 \%$ were 81 and above.

Maximum respondents in both male and female were hindus, whereas $22 \%$ males and $22 \%$ of females were Muslims. $24 \%$ were labourer and most of the males were labourer (32\%) and 20\% males do other occupation like shopkeeper, sweepers, rikshaw-chalaks, kedars and guard etc. About $24 \%$ of male respondents were agriculturist. Maximum respondents among the males $26 \%$ and females $50 \%$ were illiterate, males $28 \%$ and $24 \%$ females had primary education, $26 \%$ males and $18 \%$ females had high school education. $6 \%$ of male respondents were graduate. Maximum activity level of $43 \%$ was moderate. $68 \%$ males and 58\% females lived in nuclear families whereas $32 \%$ males and $42 \%$ females lived in joint family system.

Table 2 revealed that among 100 respondents maximum females $76 \%$ and $46 \%$ males were vegetarian, wheres $24 \%$ males and $12 \%$ females were Ovo-vegetarians. $34 \%$ males and $38 \%$ females were using mustard oil for cooking food.

$48 \%$ male and $60 \%$ female respondents didn't include salad in their diet, and whereas $52 \%$ males and $40 \%$ females include salad in their diet. Tripathi et al., (2017) suggested that green vegetables should be included in the diet of elderly to increase the iron and calcium intake and elderly people should increase their activity level and decrease the fat content to get rid of pre-obese conditions and weight management. Sweets were preferred by $70 \%$ males and $74 \%$ female respondents. In rural areas people are usually hard working so water intake of $48 \%$ and $28 \%$ males was 6-10 and 11-15 glasses respectively. If we look for females, $58 \%, 24 \%$ and $18 \%$ drink water around $6-10,11-15$ and 1-5 glasses water respectively. As, Allahpur block is a leading producer of milk and have good quantity of milk cattle so in the study it was concluded that $76 \%$ males and $82 \%$ females consume milk and milk product daily. Ghee consumption was found $66 \%$ males and $62 \%$ females. 
Nutritional status and dietary pattern in elderly population of Allahpur block in district Bijnor

Table 1: Socio-demographic data of rural elderly people in the Allahpur block in Bijnor district.

\begin{tabular}{|c|c|c|c|c|c|c|c|}
\hline S. No. & Particulars & Male & $\%$ & Female & $\%$ & $\mathrm{~N}=100$ & $\%$ \\
\hline 1. & Gender & 50 & 100 & 50 & 100 & 100 & 100 \\
\hline \multirow[t]{4}{*}{2.} & Age(Years) & & & & & & \\
\hline & $60-70$ & 35 & 70.00 & 37 & 74.00 & 72 & 72.00 \\
\hline & $71-80$ & 11 & 22.00 & 10 & 20.00 & 21 & 21.00 \\
\hline & 80 and above & 4 & 8.00 & 3 & 6.00 & 7 & 7.00 \\
\hline \multirow[t]{3}{*}{3.} & Religion & & & & & & \\
\hline & Hindu & 39 & 78.00 & 40 & 80.00 & 79 & 79.00 \\
\hline & Muslims & 11 & 22.00 & 10 & 20.00 & 21 & 21.00 \\
\hline \multirow[t]{5}{*}{4.} & Occupation & & & & & & \\
\hline & Laborers & 16 & 32.00 & 8 & 16.00 & 24 & 24.00 \\
\hline & Agriculturist & 12 & 24.00 & 5 & 10.00 & 17 & 17.00 \\
\hline & Others & 10 & 20.00 & 15 & 30.00 & 25 & 25.00 \\
\hline & No Occupation & 12 & 24.00 & 22 & 44.00 & 34 & 34.00 \\
\hline \multirow[t]{6}{*}{5.} & Education & & & & & & \\
\hline & Illiterate & 13 & 26.00 & 25 & 50.00 & 38 & 38.00 \\
\hline & Primary & 14 & 28.00 & 12 & 24.00 & 26 & 26.00 \\
\hline & High School & 13 & 26.00 & 9 & 18.00 & 22 & 22.00 \\
\hline & Intermediate & 7 & 14.00 & 4 & 8.00 & 11 & 11.00 \\
\hline & Graduation & 3 & 6.00 & - & - & 3 & 3.00 \\
\hline \multirow[t]{4}{*}{6.} & Activity Level & & & & & & \\
\hline & Light & 18 & 36.00 & 15 & 30.00 & 33 & 33.00 \\
\hline & Moderate & 21 & 42.00 & 22 & 44.00 & 43 & 43.00 \\
\hline & Heavy & 11 & 22.00 & 13 & 26.00 & 24 & 24.00 \\
\hline \multirow[t]{3}{*}{7.} & Family & & & & & & \\
\hline & Nuclear & 34 & 68.00 & 29 & 58.00 & 63 & 63.00 \\
\hline & Joint & 16 & 32.00 & 21 & 42.00 & 37 & 37.00 \\
\hline
\end{tabular}

It is evident that $88 \%$ males and $10 \%$ females use bidis and hukkas. Chewing of tobacco was done by $58 \%$ males and $4 \%$ females. None of the women consumed alcohol whereas $70 \%$ males did (Table 3 ).

Table 4 showed that $34 \%$ female and $24 \%$ males had loss of subcutaneous fat. $50 \%$ respondents were found normal in appearance whereas $21 \%$ of total respondents were with extra fat or chubby in appearance. Nails of $74 \%$ males and $64 \%$ females were appeared normal. $22 \%$ males and $34 \%$ females were having transverse lines on their nails. Out of 100 respondents $45 \%$ had broken teeth whereas $28 \%$ and $27 \%$ had carries and normal teeth respectively. $78 \%$ females and $76 \%$ males were having normal appetite. $72 \%$ females and $64 \%$ males were suffering from joint pain. Shaking of body parts like hands and head was found in $18 \%$ of total respondents. Weakness was found in $68 \%$ males and $62 \%$ females.

It is evident from Table 5 that $49 \%$ respondents were with Body mass index of normal range of 18.50-24.99 whereas, $27 \%$ were in the pre-obese range of 25-29.99. Very few were found moderately underweight i.e. $5 \%$ and $11 \%$ elderly were mildly underweight. $6 \%$ were found to be obese and $2 \%$ was found severely underweight in rural area of Allahpur Block.

A study by Drewnowski et al., (2013) assessed dietary variety in a sample of healthy older adults (age 60-70 years) as it has been reported ageing has been associated with nutritionally inadequate diets. 
Table 2: Frequency distribution of respondents according to their food habits.

\begin{tabular}{|c|c|c|c|c|c|c|c|}
\hline $\begin{array}{l}\text { S. } \\
\text { No. }\end{array}$ & Particulars & $\begin{array}{l}\text { Male } \\
\mathrm{n}=\mathbf{5 0}\end{array}$ & $\%$ & $\begin{array}{l}\text { Female } \\
\mathbf{n}=\mathbf{5 0}\end{array}$ & $\%$ & $\mathbf{N}=\mathbf{1 0 0}$ & $\%$ \\
\hline \multirow[t]{4}{*}{1} & \multicolumn{7}{|l|}{ Food habits } \\
\hline & Vegetarian & 23 & 46.00 & 38 & 76.00 & 61 & 61.00 \\
\hline & Non-vegetarian & 15 & 30.00 & 6 & 12.00 & 21 & 21.00 \\
\hline & Ovo-vegetarian & 12 & 24.00 & 6 & 12.00 & 18 & 18.00 \\
\hline \multirow[t]{3}{*}{2} & \multicolumn{7}{|l|}{ Meal type } \\
\hline & Small frequent & 24 & 48.00 & 21 & 42.00 & 45 & 45.00 \\
\hline & Heavy Meal & 26 & 52.00 & 29 & 58.00 & 55 & 55.00 \\
\hline \multirow[t]{4}{*}{3} & \multicolumn{7}{|c|}{ Water intake(glasses) } \\
\hline & $1-5$ & 12 & 24.00 & 9 & 18.00 & 21 & 21.00 \\
\hline & $6-10$ & 24 & 48.00 & 29 & 58.00 & 53 & 53.00 \\
\hline & $11-15$ & 14 & 28.00 & 12 & 24.00 & 26 & 26.00 \\
\hline \multirow[t]{3}{*}{4} & \multicolumn{7}{|l|}{ Salad inclusion } \\
\hline & Yes & 26 & 52.00 & 20 & 40.00 & 46 & 46.00 \\
\hline & No & 24 & 48.00 & 30 & 60.00 & 54 & 54.00 \\
\hline \multirow[t]{3}{*}{5} & \multicolumn{7}{|c|}{ Milk/milk product consumption } \\
\hline & Yes & 38 & 76.00 & 41 & 82.00 & 79 & 79.00 \\
\hline & No & 12 & 24.00 & 9 & 18.00 & 21 & 21.00 \\
\hline \multirow[t]{3}{*}{6} & \multicolumn{7}{|c|}{ Sugar/sweet consumption } \\
\hline & Yes & 35 & 70.00 & 37 & 74.00 & 72 & 72.00 \\
\hline & No & 15 & 30.00 & 13 & 26.00 & 28 & 28.00 \\
\hline \multirow[t]{3}{*}{7} & \multicolumn{7}{|l|}{ Fat consumption } \\
\hline & Ghee & 33 & 66.00 & 31 & 62.00 & 64 & 64.00 \\
\hline & Mustard oil & 17 & 34.00 & 19 & 38.00 & 36 & 36.00 \\
\hline
\end{tabular}

Table 3: Frequency distribution of respondents according to consumption of harmful substances.

\begin{tabular}{|c|c|c|c|c|c|c|c|}
\hline S. No. & Particulars & $\begin{array}{l}\text { Male } \\
\mathbf{n}=50\end{array}$ & $\%$ & $\begin{array}{c}\begin{array}{c}\text { Female } \\
\mathbf{n}=50\end{array} \\
\text { che }\end{array}$ & $\%$ & $\mathrm{~N}=\mathbf{1 0 0}$ & $\%$ \\
\hline \multirow[t]{3}{*}{1} & \multicolumn{7}{|c|}{ Consumption of Bidis, Hukka } \\
\hline & Yes & 44 & 88.00 & 5 & 10.00 & 49 & 49.00 \\
\hline & No & 6 & 12.00 & 45 & 90 & 51 & 51.00 \\
\hline \multirow[t]{3}{*}{2.} & \multicolumn{7}{|c|}{ Consumption of Tobacco(chewing) } \\
\hline & Yes & 28 & 56.00 & 4 & 8.00 & 32 & 32.00 \\
\hline & No & 22 & 44.00 & 46 & 92.00 & 68 & 68.00 \\
\hline \multirow[t]{3}{*}{3.} & \multicolumn{7}{|c|}{ Consumption of Alcohol } \\
\hline & Yes & 35 & 70.00 & - & - & 35 & 35.00 \\
\hline & No & 15 & 30.00 & 50 & 100.00 & 65 & 65.00 \\
\hline
\end{tabular}


Nutritional status and dietary pattern in elderly population of Allahpur block in district Bijnor

Table 4: Frequency distribution of respondents according to clinical assessment

\begin{tabular}{|c|c|c|c|c|c|c|c|}
\hline S. No. & Particulars & $\begin{array}{l}\text { Male } \\
\mathrm{n}=50\end{array}$ & $\%$ & $\begin{array}{l}\text { Female } \\
\mathbf{n}=\mathbf{5 0}\end{array}$ & $\%$ & $\mathbf{N}=\mathbf{1 0 0}$ & $\%$ \\
\hline \multirow[t]{4}{*}{1} & \multicolumn{7}{|l|}{ General appearance } \\
\hline & $\begin{array}{l}\text { Loss of subcutaneous } \\
\text { fat }\end{array}$ & 12 & 24.00 & 17 & 34.00 & 29 & 29.00 \\
\hline & Normal & 27 & 54.00 & 23 & 46.00 & 50 & 50.00 \\
\hline & Chubby & 11 & 22.00 & 10 & 20.00 & 21 & 21.00 \\
\hline \multirow[t]{4}{*}{2} & \multicolumn{7}{|l|}{ Nails } \\
\hline & Spooning & 2 & 4.00 & 1 & 2.00 & 3 & 3.00 \\
\hline & Transverse lines & 11 & 22.00 & 17 & 34.00 & 28 & 28.00 \\
\hline & Normal & 37 & 74.00 & 32 & 64.00 & 69 & 69.00 \\
\hline \multirow[t]{4}{*}{3} & \multicolumn{7}{|l|}{ Teeth } \\
\hline & Broken teeth & 21 & 42.00 & 24 & 48.00 & 45 & 45.00 \\
\hline & Carries & 17 & 34.00 & 11 & 22.00 & 28 & 28.00 \\
\hline & Normal & 12 & 24.00 & 15 & 30.00 & 27 & 27.00 \\
\hline \multirow[t]{4}{*}{4} & \multicolumn{7}{|l|}{ Skin quality } \\
\hline & Dry & 10 & 20.00 & 11 & 22.00 & 21 & 21.00 \\
\hline & Pale & 12 & 24.00 & 10 & 20.00 & 22 & 22.00 \\
\hline & Normal & 28 & 56.00 & 29 & 58.00 & 57 & 57.00 \\
\hline \multirow[t]{3}{*}{5} & \multicolumn{7}{|l|}{ Appetite } \\
\hline & Normal & 38 & 76.00 & 39 & 78.00 & 77 & 77.00 \\
\hline & Anorexia & 12 & 24.00 & 11 & 22.00 & 23 & 23.00 \\
\hline \multirow[t]{3}{*}{6} & \multicolumn{7}{|l|}{ Joint Pain } \\
\hline & Present & 32 & 64.00 & 36 & 72.00 & 68 & 68.00 \\
\hline & Absent & 18 & 36.00 & 14 & 28.00 & 32 & 32.00 \\
\hline \multirow[t]{3}{*}{7} & \multicolumn{7}{|c|}{ Parkinson syndrome(shaking of body parts) } \\
\hline & Present & 12 & 24.00 & 6 & 12.00 & 18 & 18.00 \\
\hline & Absent & 38 & 76.00 & 44 & 88.00 & 82 & 82.00 \\
\hline \multirow[t]{3}{*}{8} & \multicolumn{7}{|l|}{ Weakness } \\
\hline & Yes & 34 & 68.00 & 31 & 62.00 & 65 & 65.00 \\
\hline & No & 16 & 32.00 & 19 & 38.00 & 35 & 35.00 \\
\hline
\end{tabular}

Table 5: Frequency distribution according to the clinical assessment

\begin{tabular}{|l|l|c|c|}
\hline BMI $\left(\mathbf{k g} / \mathbf{m}^{\mathbf{2}}\right)$ & Results & $\mathbf{N = 1 0 0}$ & $\mathbf{\%}$ \\
\hline$<16$ & Severe underweight & 2 & 2.00 \\
\hline $16-16.99$ & Moderate underweight & 5 & 5.00 \\
\hline $17-18.49$ & Mild underweight & 11 & 11.00 \\
\hline $18.50-24.99$ & Normal range & 49 & 49.00 \\
\hline $25-29.99$ & Pre- obese & 27 & 27.00 \\
\hline$>30$ & Obese & 6 & 6.00 \\
\hline
\end{tabular}

\section{Conclusions and Recommendations}

From the study it was concluded that maximum respondents were healthy and very few were malnourished. The food habits of elderly population were found to be efficient. Maximum respondents were appearing healthy however; many had joint pains as many were lightly or moderately active. Majority of respondents had tooth caries and decay due to excessive use of Bidis and Hukkas. The Allahapur block of district Bijnor has healthy environment in terms of elderly. Green vegetables should be included in the diet to increase the iron and calcium intake. Healthy lifestyle and food habits should be maintained through adopting healthy lifestyle practices. Consumption of harmful substances such as 
cigarette, drinking tobacco etc. should be avoided or restricted. Elderly people should increase their activity level and decrease the fat content to get rid of joint pain. Bidis, hukkas, tobacco and alcohol should be consumed in limit to maintain teeth, regulate digestion and prevent respiratory problems. Small meals should be taken instead of heavy meals to control diabetes, obesity and indigestion. If possible, Regular doctor checkup should be taken in every 1 year to keep an eye for any disorder and proper functioning of organs of the body.

\section{References}

1. Arulmani, J.J. and John, S., (2004). Study on the factors contributing to the nutritional status of elderly. The Indian Journal of Dietetics, 34: 241-249.

2. Barrett, P., Twitchin, S. And Kletchko, S. (2006). The living environments of community-dwelling older people who become frail: another book at the Living Standards of Older New Zealanders Survey". Social Policy Journal of New Zealand, 28; 133-157.

3. Bates, C.J., Benton, D., Biesalski, H.K., Staehelin, H.B., Van Staveren, W., Stehle, P., Suter, P.M. and Wolfram, G.(2002). Nutrition and Aging: A Consensus Statement. Journal of Nutrition and Health Aging, 6: 103-160.

4. Drewnowski, A., Henderson, S.A., Driscoll, A. and Rolls, B.J. (2013).The dietary variety score: Assessing diet quality in healthy young and older adults. Journal of American Diet Association, 97: 266-271.

5. Fiatarone, M.A., O’Neill, E.F., Ryan, N.D., Clements, K.M., Solares, G.R., Nelson, M.E., Roberts, S.B., Kehayias, J.J., Lipsitz, L.A. and Evans, W.J. (1994). Exercise training and nutritional supplementation of physical fraility in every elderly people. New England Journal of Medicine, 330: 1769-1775.

6. Joshi, Subhangini A (2010) "Nutrition and Dietetics". Introduction to Nutrition and Dietetics, pp. 5.

7. Nijs, K.A., de Graaf, C., Siebelink, E., Blauw, Y.H., Vanneste, V., Kok, F.J. and van Staveren, W.A. (2006). Effect of family-style meals on energy intake and risk of malnutrition in dutch nursing home residents: a randomized controlled trial. Journal of Gerontology: Series A, Biological Sciences and Medical Sciences, 61: 935-42b

8. Orman, M.L. and Hotley, J.E. (2000). Assessment of protein energy malnutrition in older person: History Examination, body composition, and screening tools. British Journal of Nutrition, 16: 50-63.

9. Saeidlou, S.N., Merdol, T.K, Mikaili, P. and Bektaş (2011). Assessment of the nutritional status and affecting factors of elderly people living at six nursing homes in Urmia, Iran. Journal of Academic Research, 3(1): 173-182

10. Tripathi, K.M., Sharma, J.P., Dubey, S.K., Selvan, T., Kumar, M. (2017). Nutritional status and dietary pattern in geriatric population of rural Bulandshahr of western Uttar Pradesh. Journal of Community Mobilization and Sustainable Development, 12(1): 31-36.

\begin{tabular}{|ll|}
\hline Received & : August, 2017 \\
Revised & : Sept., 2017 \\
Published & : Dec., 2017 \\
\hline
\end{tabular}

